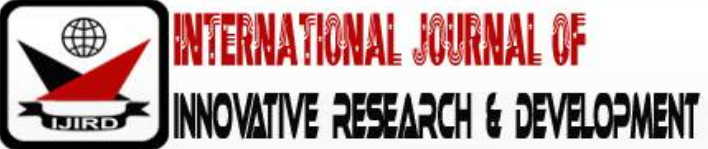

ISSN 2278 - 0211 (Online)

\section{Residents' Perception on the Challenges of Accessing Potable Water in the Rural Areas of Taraba State, Nigeria}

\begin{tabular}{|c|}
\hline Moahammed Bakoji Yusuf \\
Senior Lecturer, Department of Geography, Taraba State University, Jalingo, Nigeria \\
Anita Humshe Philip \\
Lecturer, Department of Geography, Taraba State University, Jalingo, Nigeria \\
Umar Jauro Abba \\
Lecturer, Department of Geography, Taraba State University, Jalingo, Nigeria \\
Isa, Mohammed Saleem \\
Lecturer, Department of Geography, Taraba State University, Jalingo, Nigeria \\
Iraru Yusuf \\
Student, Department Land Surveying, Office of the Surveyor General, Taraba State, Nigeria
\end{tabular}

\begin{abstract}
:
The objective of the study was to investigate the challenges encounter in the course of water search in the rural areas of Taraba State. The use of open and closed-ended questionnaires, oral interviewed and personal observations was conducted in the study-region. The results show that there was adequate awareness of the people on different forms of challenges constraining the easy search for water in the study region. The results also show that long distance trek to the source of water and the time taken to acquire water were the major challenges constraining the search for water in the just named location. The results further show that artificial water scarcity and government insincerity were the major reasons for the challenges furthermore the majority of the population in the study region depends on surface water sources. The study therefore, recommends that: 1. the people of the study region should adopt various methods of water collection (like rain water collection and construction of reservoirs or dams) and storage and avoid misuse of water. 2. Both public and private institutions should give appropriate attention to the provision and maintenance of potable water sources in the rural areas.
\end{abstract}

Keywords: Challenges, Nigeria, rural water, Taraba State

\section{Introduction}

Water is a natural resource of fundamental importance. It is a common factor to the five basic human needs namely air, water, food, light and heat (Peter \& Reed, 2004). Water constitutes about 80\% of animal cells (Mwendera, 2006). The human body by weight consists of about $70 \%$ water and several body functions depend on water (Human Development Report, 2006). It is therefore, not an understatement to say water is life because it forms an appreciable proportion of all living things including man.However, the supply of domestic water has remained the global single most important environmental and economic problem affecting mankind (Mwendera, 2006; Ntengwe, 2005).Although, the magnitude of the scarcities varies greatly over space and time and depends on the sensitivity and resilient nature of the water resources as well as water management policies and practices in use. The severity of the inadequacy is particularly more severe in the rural regions of the Sub-Saharan African countries where its demand has fast outpaced its availability for consumption (Yunanaet al., 2016). Inadequate water supply, constant hunger; severe thirst and tension, conflicts among users, low quality of life, and excessive pressure on the environment constraining the region are the consequent of the pressure on water resources (Ajayiet al., 2003; Udo \& Etim, 2007).

In Nigeria, where the level of poverty is high and population increases is among the highest in the world with more than two-third of its populace living in the rural areas call for increase allocation of groundwater and surface water for domestic, agricultural and industrial sector uses(UN report 2016). Conversely, Nigerian water availability per capital is decreasing and ranked as least in the world with 3,800M3/capital per year a little more than half the world average of 7000M3(Peter \& Reed, 2004; Yunanaet al., 2016). It was projected that; if the present trend of decrease in domestic water availability (31.5\%)continues unabated, its availability per capital by 2025 maybe 65\% less than the world average $7000 \mathrm{M} 3$ while, over 40 million people living in rural areas will face absolute water scarcity and two-thirds of the rural lands comes under stress condition (Ajayi et al., 2003; Ellen \& Kellog, 2005; Tasiuet al., 2006; Yunanaet al., 2016). The major sources of domestic water supply for most of the rural populaces in Nigeria particularly the northeastern part of the country to which the study region belong are highly unreliable during the dry seasons (Makoniet al., 2004).The differences in elevation are instrumental to the level of variation in the amount of precipitation received.Moreover, given the fact that 
every human being has the right to have access to sufficient water for personal and domestic uses, which must be safe, acceptable, affordable and physically accessible (Peter \& Reed, 2004). Therefore, assessing the challenges of accessing clean, reliable and potable water in rural areas has remained a task considering the fact that the larger percentage of the Nigerian population lives in rural areas. Furthermore, access to quality water is keyed to economic prosperity and better living standards. Researches including those of Yunana et al., (2016), Tasiu et al., (2006) and Abaje et al., (2009), have revealed that about $40 \%$ of children in Nigeria are deprived of educational pursuit as a result of domestic activities such as the search for water. While, Hope (2006), and Nura\& Sabo (2011), revealed that the slow and low level of economic productivities and consequently poverty, overstress, high illiteracy level and high dependency ratio in most rural areas are consequences of water scarcities. This is worrisome considering the fact the 17 SDGs achievements is dependent on the achievement of goal 6 which is on water and sanitation. However, despite, the numerous studies conducted on water supply in Nigeria generally and in Taraba State, in particular, few studies have been conducted on investigating the challenges encountered in the search of rural water using residents' perception. Moreover, such few studies are scanty, and far between. Also, in face of the rapidly growing population, people needs water to survive, researchers such as(Gilbert, 2005; Hope, 2006; Nura \& Sabo, 2011; Yunana et al., 2016) and notable institutions such as Human Development Report, (2006); United Nations Report (2010); World Meteorological Organization, (2008), have challenged researchers to venture into assessing the challenges of rural water search for sustainable water supply and management in the world and sub-Saharan African countries in particular and Nigeria inclusive. Given that, local scale studies such as this are critical to the design of regional appropriate water supply and economic development interventions. Therefore, the present study seeks to investigate residents' perception on the challenges encountered in the course of searching water in rural areas of Taraba State with a view to gaining a better understanding of the major types of the challenges. This desire is connected with the agricultural, residential, engineering and industrial support potentials of the study region.

\section{The Study Area}

The study was conducted in Taraba State, located in northeastern Nigeria.Fig.1. The study area is characterized by a unimodal rainfall regime with an extended rainy season from April to October (Taraba State Government, 2017; Yusuf \& Ray, 2011). Over three decades period, the average annual rainfall was $1100 \mathrm{~mm}$ and the mean maximum temperature was about 240C, while the minimum temperature ranged between 150C and 180C (Odjugo, 2010). Evaporation and transpiration are very high in this area, especially during the dry season. In the northern and central part of Taraba State, undulating slopes divided by V-shaped valleys of seasonal and/or relatively permanent streams characterize the topography of the study area (Umar, 2013;Yusuf, 2008). Very steep slopes are found along the valley sides, where slopes greater than $30 \%$ are very common (Ola, 1978). The study region has a total surface area of $54,473 \mathrm{~km} 2$, a total population of $3,066,800$ inhabitants in 2018, with a projected annual growth rate of 3.1 percent (NPC, 2019).

\section{Methods}

The data used for the study were generated through a structured questionnaire survey of 480 respondents, by lot. The sampling techniques were undertaken in four stages: Firstly, the study region was divided into three Senatorial Zone (SZs) and used as clusters for sampling purposes. Secondly, from these clusters (SZs), 6 Local Government Areas (2LGAs from, and constituting 40\% of the LGA in each SZs) were randomly selected. Thirdly, from each of the 6 Local Government Areas sampled, 15 villages were randomly selected. Thus, forming a sample size of 90 villages, in which the questionnaire was administered, and fourthly, a total of 480 respondents were randomly selected and used for this research. The proportion of these respondents (480) in each sample village was obtained using the Cochran 1977 proportional allocation techniques formula, thus:

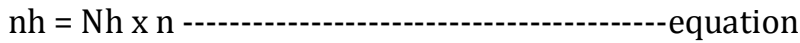

$\mathrm{N}$

Where, $\mathrm{nh}=$ the number of the individual sample villages

$\mathrm{Nh}=$ the number of households in the individual village

$\mathrm{n}=$ the number of questionnaires to be distributed to the sample villages.

$\mathrm{N}=$ the total number of persons in the sample villages.

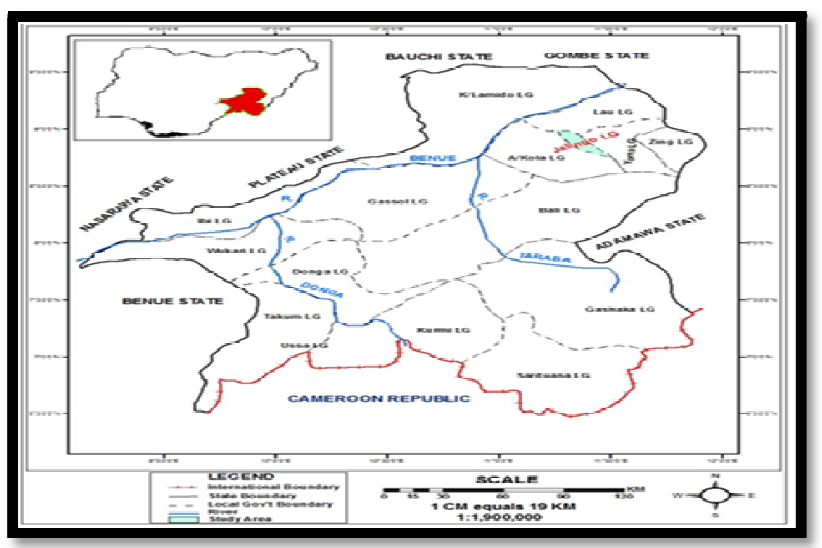

Figure 1: Map of Taraba State Showing the Sampled Local Government Area 


\section{Results and Discussion}

This section introduces and talks over the results in three successive sections. The first segment deals with some personal and demographic characteristics of respondents. The second section examines residents' sources of water supply. Lastly, the third section discusses the residents' types and reasons for challenges encountered in the course ofaccessing portable water in the region.

\begin{tabular}{|c|c|c|c|c|c|c|c|c|c|c|}
\hline \multirow[t]{3}{*}{ HDC } & \multicolumn{6}{|c|}{ Local Government Areas } & \multirow[t]{3}{*}{ Total } & \multirow[t]{3}{*}{$\%$} & \multirow[t]{3}{*}{$\mathrm{X}^{2}$ Value } & \multirow[t]{2}{*}{ Sig } \\
\hline & \multicolumn{2}{|c|}{ Northern Zone } & \multicolumn{2}{|c|}{ Central Zone } & \multicolumn{2}{|c|}{ Southern Zone } & & & & \\
\hline & Yorro & Zing & Bali & Gashaka & Takum & Wukari & & & & \\
\hline & $\%$ & $\%$ & $\%$ & $\%$ & $\%$ & $\%$ & & & & \\
\hline & $(n=70)$ & $(n=80)$ & $(n=73)$ & $(n=83)$ & $(n=84)$ & $(n=90)$ & & & & \\
\hline \multicolumn{11}{|l|}{ Gender } \\
\hline $\mathrm{M}$ & 25 & 18 & 30 & 23 & 30 & 34 & 160 & 33.4 & \multirow{27}{*}{$\begin{array}{c}\mathrm{X}^{2}=46.808 \\
\mathrm{df}=35 \\
\mathrm{p}>.05\end{array}$} & \multirow[t]{27}{*}{ NS } \\
\hline $\mathrm{F}$ & 45 & 62 & 43 & 60 & 54 & 56 & 320 & 66.6 & & \\
\hline Age & & & & & & & & & & \\
\hline 18-35 years & 57 & 55 & 39 & 21 & 61 & 65 & 298 & 62.1 & & \\
\hline $36-50$ years & 12 & 17 & 30 & 59 & 20 & 20 & 158 & 32.9 & & \\
\hline Above 51 years & 1 & 8 & 4 & 3 & 3 & 5 & 24 & 5 & & \\
\hline \multicolumn{9}{|l|}{ Marital Status } & & \\
\hline Single & 9 & 11 & 10 & 13 & 8 & 18 & 69 & 14.4 & & \\
\hline Married & 58 & 67 & 53 & 64 & 71 & 68 & 381 & 79.4 & & \\
\hline Divorced/Widows & 3 & 2 & 10 & 6 & 5 & 4 & 30 & 6.2 & & \\
\hline \multicolumn{9}{|l|}{ Family Size } & & \\
\hline 1-4 individuals & 23 & 31 & 22 & 37 & 20 & 27 & 160 & 33.3 & & \\
\hline 5-8 individuals & 46 & 49 & 43 & 38 & 45 & 50 & 271 & 56.5 & & \\
\hline 9 and above individuals & 1 & 0 & 8 & 8 & 19 & 13 & 49 & 10.2 & & \\
\hline \multicolumn{9}{|l|}{ Educational Level } & & \\
\hline Informal education & 51 & 40 & 38 & 42 & 42 & 32 & 245 & 51.0 & & \\
\hline Primary education & 4 & 23 & 12 & 22 & 25 & 29 & 115 & 24.0 & & \\
\hline Secondary education & 9 & 9 & 21 & 13 & 13 & 25 & 90 & 18.8 & & \\
\hline Tertiary education & 6 & 8 & 2 & 6 & 4 & 4 & 30 & 6.3 & & \\
\hline \multicolumn{9}{|l|}{ Monthly Income (N) } & & \\
\hline Below 15,000 & 20 & 31 & 18 & 25 & 32 & 32 & 158 & 32.9 & & \\
\hline $16000-25,000$ & 21 & 19 & 18 & 28 & 26 & 28 & 140 & 29.2 & & \\
\hline $26,000-35,000$ & 11 & 9 & 14 & 15 & 10 & 8 & 67 & 14.0 & & \\
\hline $36,000-45,000$ & 7 & 8 & 9 & 8 & 4 & 6 & 42 & 8.8 & & \\
\hline $46,000-55,000$ & 5 & 7 & 5 & 3 & 4 & 7 & 31 & 6.5 & & \\
\hline $56,000-65,000$ & 3 & 4 & 6 & 2 & 4 & 6 & 25 & 5.2 & & \\
\hline 66,000 and above & 3 & 2 & 3 & 2 & 4 & 3 & 17 & 3.5 & & \\
\hline
\end{tabular}

Table 1: Demographic Characteristics of Respondents

Source: Field Survey, 2019

Findings in Table 1 show that out of the 480respondents interviewed, a greater proportion (66.6\%) was female and (33.4\%) were Male. A condition that suggests gender discrimination with respect to water supply, where water supply activities are female dominated in the study region. Majority of the respondents were within the age bracket of 18-35 years(62.1\%). Significant proportions of the respondents, indicated by (79.4\%) were married and had a family size of 5-8 individuals (56.9\%). Findings on education level indicate that a significant proportion of the respondents (51.0\%)had no formal education and the majority $62.1 \%$ earned bellows N26, 000 only as monthly incomes. The low level of monthly income among the people as recognized from the in-depth interview was their over-dependent on their farms' produce as their source of income. Thus, the inadequate or low level of formal education and poverty (no off-farm income) are two key characteristics, which impact on people perceptions, which result in the low level of monthly income. However, there were no significant differences recorded between respondents in relation to gender, age groups, marital status, family size, educational background and monthly income level. Therefore, research communities were deemed demographically quite similar in household characteristics.

\begin{tabular}{|c|c|c|c|c|c|c|c|c|}
\hline \multirow{2}{*}{ Sources } & \multicolumn{2}{|c|}{ Northern zone } & \multicolumn{2}{c|}{ Central zone } & \multicolumn{2}{c|}{ Southern zone } & Total & \multirow{2}{*}{ Percentage (\%) } \\
\cline { 2 - 8 } & Yorro & Zing & Bali & Gashaka & Takum & Wukari & & \\
\hline Hand-dug wells & 16 & 18 & 21 & 21 & 15 & 13 & 104 & 21.7 \\
\hline Borehole & 21 & 13 & 23 & 11 & 15 & 21 & 104 & 21.7 \\
\hline Stream/ River & 30 & 43 & 29 & 47 & 47 & 51 & 247 & 51.5 \\
\hline Natural springs & 3 & 4 & & 2 & 6 & 4 & 19 & 3.9 \\
\hline Rainfall harvest & & 2 & & 2 & 1 & 1 & 6 & 1.2 \\
\hline
\end{tabular}

Table 2: Sources of Water in the Rural Communities of Taraba State

Source: Field Survey, 2019 
The finding in Table 2 indicates that the majority of the populations (51.5\%) in the study area depend on surface water sources (rivers and streams)as their sources of water. A condition that suggests the presence of inadequate and poor sources of water supply as most of the streams/rivers dries up during the dry season. This finding agrees with the statements of Rossiteret al., (2010), that rural communities in many developing nations obtain their water from untreated surface sources which are often situated far away from their residence and also congruent with the finding of Mwendra, (2006) that 'the major sources of water supply for the rural populace are the natural springs, streams, and rivers'

\begin{tabular}{|c|c|c|c|c|c|c|c|c|}
\hline Challenges & \multicolumn{2}{|c|}{$\begin{array}{c}\text { Northern } \\
\text { zone }\end{array}$} & \multicolumn{2}{|c|}{ Central zone } & \multicolumn{2}{|c|}{ Southern zone } & Total & $\begin{array}{c}\text { Percentage } \\
\text { (\%) }\end{array}$ \\
\cline { 2 - 9 } & Yorro & Zing & Bali & Gashaka & Takum & Wukari & & \\
\hline $\begin{array}{c}\text { Long distance trek to } \\
\text { water source }\end{array}$ & 19 & 38 & 21 & 21 & 35 & 25 & 159 & 33.1 \\
\hline $\begin{array}{c}\text { Time taken to acquire } \\
\text { water }\end{array}$ & 21 & 17 & 23 & 29 & 18 & 23 & 131 & 27.3 \\
\hline $\begin{array}{c}\text { Long queueto acquire } \\
\text { water }\end{array}$ & 15 & 13 & 20 & 21 & 20 & 31 & 120 & 25.0 \\
\hline $\begin{array}{c}\text { Conflict among residents } \\
\text { over water }\end{array}$ & 15 & 12 & 9 & 12 & 11 & 11 & 70 & 14.6 \\
\hline
\end{tabular}

Table 3: Challenges Encountered by Respondents in the Search for Water Source: Field Survey, 2019

From Table 3 the results indicate that long distance trek to the water source $33.1 \%$, the time taken to acquire water $27.3 \%$, and long queue in acquiring water $25.0 \%$, were the most widely cited challenges faced in the search for water in the rural communities of Taraba State. This findings is consistent with similar findings reported by Ellen \& Kellog (2005);Tittonell, et al.,(2006), across different parts of Africa and Okeke et al., (2013); Okoye et al., (2008), in Nigeria. Based on oral interviewed conducted, most residents interviewed confirmed the above findings, when some stated that they are aware of the different forms of challenges constraining the easy search for water in the study region, but they are forced to stay in the rural areas because crop cultivation, animals grazing, and inheritance. Thus, in conformity with the idea that most African rural areas are greatly impacted negatively in the easy access to adequate clean water due to their location and socio-economic status.

\begin{tabular}{|c|c|c|c|c|c|c|c|c|}
\hline $\begin{array}{c}\text { Reasons for the } \\
\text { challenges }\end{array}$ & \multicolumn{2}{|c|}{$\begin{array}{c}\text { Northern } \\
\text { zone }\end{array}$} & \multicolumn{2}{c|}{ Central zone } & \multicolumn{2}{c|}{ Southern zone } & Total & $\begin{array}{c}\text { Percentage } \\
\text { (\%) }\end{array}$ \\
\cline { 2 - 8 } & Yorro & Zing & Bali & Gashaka & Takum & Wukari & & \\
\hline $\begin{array}{c}\text { Government } \\
\text { insincerity }\end{array}$ & 15 & 15 & 20 & 19 & 20 & 13 & 102 & 21.2 \\
\hline $\begin{array}{c}\text { Inadequate } \\
\text { information }\end{array}$ & 15 & 13 & 5 & 10 & 14 & 11 & 68 & 14.2 \\
\hline $\begin{array}{c}\text { Artificial water } \\
\text { scarcity }\end{array}$ & 16 & 37 & 25 & 28 & 25 & 41 & 172 & 35.8 \\
\hline $\begin{array}{c}\text { Policy issues and } \\
\text { perspectives }\end{array}$ & 21 & 13 & 18 & 16 & 14 & 13 & 95 & 19.8 \\
\hline Poor maintenance & 3 & 2 & 5 & 10 & 11 & 12 & 43 & 9.0 \\
\hline
\end{tabular}

Source: Field Survey, 2019

From Table 4 the results indicate that artificial water scarcity,35.8\%, and government insincerity $21.2 \%$ were the most widely cited reasons for the challenges faced in the search for water in Taraba State. A relatively small percentage of the respondents, $19.8 \%$, and $14.2 \%$, respectively, mentioned policy issues and perspectives, and inadequate information as the major reasons for the challenges in the search for water in the area. While the least mentioned reason was poor maintenance $9.0 \%$. This means that the majority of the people in the study region perceived natural and institutional factors as the main reason for rural water challenges. This suggests, therefore, that the majority of the people in the research region do not see rural water challenges as an individual problem. Most of the people interviewed confirmed these reasons. For example, one respondent expressed the opinion that neither public nor private institutions had given appropriate attention to provision and maintenance of potable water sources in the rural areas.These results, therefore, give a clear picture of the level of the residents' awareness and the magnitude of the challenges of accessing an acceptable level of potable water supply in rural areas of Taraba state.

\section{Conclusion}

The research examined the challenges of rural water accessibility in Taraba state with a view to gaining a better understanding of the major types of the challenges. Clearly, the findings show that there is high level of awareness of the different forms of challenges constraining the easy search for water in the study region. This awareness suggests, therefore, that the water scarcity problem is a serious issue in the study region. Long distance trek to the source of water 
and the time taken to acquire water were the major challenges constraining the search for water in the rural areas of Taraba State. The results further show that artificial water scarcity and government insincerity were the major reasons for the challenges and the majority of the population in the study region depends on surface water sources. The study therefore, recommends that: 1 . The people of the study region should adopt various methods of water collection (like rain water collection and construction of reservoirs or dams) and storage and avoid misuse of water. 2. Both public and private institutions should give appropriate attention to the provision and maintenance of potable water sources in the rural areas

\section{Acknowledgments}

The authors acknowledge with appreciation the efforts of the people in the study region for their collaboration in an interview.

\section{References}

i. Abaje, I. B., O.F., A., \& Ishaya, S. (2009). Nature of Potable Water Supply and Demand in Jema`a local Government Area of Kaduna State, Nigeria. . Journal of Environmental and Earth sciences., 8, 16-21.

ii. Ajayi. J.O, Sonuga, F. A., Aliboh, O. P., \& Oloke, D. A. (2003). Sustainable Potable Water Supply to Nigeria through Conjunctive Development of Surface and Ground and Ground Water Resources. . Journal of Environment and Earth Sciences., 4(9).

iii. Ellen, J., \& Kellog, J. S. (2005). Deficiencies in Drinking Water Distribution Systems in Developing Countries.

iv. Gilbert, K. (2005). Challenges of Rural Water Sub Sector Reform within the context of Decentralization in Uganda. Directorate of Water Development (DWD) Ministry of Water, lands and Environment, Kampala, Uganda.

v. Hope, R. (2006). Evaluating Water Policy Scenarios against the Priorities of the Rural Poor. International journal of Earth science., 2, 167-179.

vi. Human Development Report. (2006). United Nations Development Programme. Human Development Report Office occasional paper.

vii. Makoni, F., Manaseh, G., \& Ndamba, J. (2004). Patterns of Domestic Water use in Rural Areas of Zimbabwe. Journals of Physics and Chemistry, parts A/B/C. ,2,162-166.

viii. Mwendera, E. J. (2006). Rural Water Supply and Sanitation (RWSS) Coverage in Swaziland: towards Achieving Millennium Development Goals. Journal of Physics and Earth Chemistry., 8, 681-689.

ix. NPC. (2017). National Population Commission of Nigeria.

x. Ntengwe, F. W. (2005). Integrated Water Resources Management (IWRM) and the Millennium Development Goals: Managing Water Peace and Prosperity. Journal of Physics and Chemistry of the Earth., 30, 623-992. .

xi. Nura, A., \& Sabo, M. (2011). Determinant Of Household Demand For Water in Kano Metropoli:A Crisis Sectional Analysis. . Kano Journal of Arts and Social Sciences, , 8.

xii. Odjugo, P. A.-a. O. (2010). General overview of climate change impacts in Nigeria. Journal of Human Ecology, 29(1), 47-55.

xiii. Ola, S. A. (1978). The geology and geotechnical properties of the black cotton soils of northeastern Nigeria. Engineering Geology, 12, 375-391.

xiv. Peter, H., \& Reed, B. (2004). Rural Water Supply In Africa. Building Blocks for Hand Pump Sustainability. (Loughborough University Leicestershire).

xv. Rossiter, H., Owusu, P., Awuah, E., Macdonald, A., \& Schafer, A. (2010). Chemical Drinking Water In Ghana:Water Cost And Scope For Advance Treatment. . The Journal of Environmental Sciences, 11, 2378-2386.

xvi. Taraba State Government. (2017). Taraba State Physical Setting, Peoples and Culture. Retrieved from http://www.onlinenigeria.com/links/sendmail.asp

xvii. Tasiu, Y., Iguisi, E., \& Mallam, I. (2006). Assessment of Water Supply Situation in the Rural Areas of Kano State, Northern Nigeria. Global Research. Journal of Agricultural Science., 5(1), 033-041.

xviii. Udo, M., \& Etim, L. (2007). Evaluation of the Ecological Impact of Human Settlement on the Water quality of Lower Cross River State, Nigeria. Research Journal of Environmental Science., 10, 1155-2013.

xix. Umar, D. (2013). The effects of land use on stream communities in highland tropical Nigeria.

xx. United Nations Report (2010). Report on the World Social Situation 2010.

xxi. World Meteorological Organization. (2008). Water and Climate Change. No. 970 Geneva, Switzerland. World Walk for Water (2010).

xxii. Yunana, M., Danjuma, P., Bonet, R., \& Siaka, S. (2016). The Challenges of Rural Water Supply in Nigeria. Dynamic Journal of Environmental Science and Technology., 1(4), 24-30.

xxiii. Yusuf, M. B. (2008). Farmers' Perception and Responses to Soil Erosion In Zing local Government Area of Taraba State, Nigeria. (Unpublished Master's Thesis), Federal University of Technology, Yola, Nigeria.

xxiv. Yusuf, M. B., \& Ray, H. H. (2011). Farmers' Perception and Reponses to Soil erosion in Zing Local Government Area of Taraba State, Nigeria. Ethiopian Journal of Environmental Studies and Management, 4(1), 93-98. doi:10.4314/ejesm.v4i1. 